\title{
Serum Magnesium Measurement
}

National Cancer Institute

\section{Source}

National Cancer Institute. Serum Magnesium Measurement. NCI Thesaurus. Code C61035.

A quantitative measurement of the amount of magnesium present in a sample of serum. 